\title{
Impact of Globalization and Internationalization Processes on Added Value in EU Countries
}

\author{
Yaroslava Kostiuk $^{1 *}$, Eva Kalinová2 ${ }^{2}$ and Jiři Kučera ${ }^{3}$ \\ ${ }^{1}$ The Faculty of Operation and Economics of Transport and Communications, Department of \\ Economics, University of Žilina. \\ ${ }^{2}$ The Faculty of Operation and Economics of Transport and Communications, Department of \\ Economics, University of Žilina. \\ ${ }^{3}$ The Faculty of Operation and Economics of Transport and Communications, Department of \\ Economics, University of Žilina.
}

\begin{abstract}
.
Research Background: The paper focuses on the specification of categories of the globalization and internationalization process in terms of origin, development, definition and content. Using European Commission statistics for the period 2013-2017, the EU28 countries are divided into countries that started the EU (Germany, France, Italy, Belgium, the Netherlands, Luxembourg) and countries that joined the EU before 2000 (Denmark, Norway, Finland, Portugal, Austria, Greece, Spain, Sweden, Great Britain), and other countries of the so-called former Eastern bloc (Czech Republic, Slovakia, Hungary, Poland). For such defined EU countries, a different level of involvement in the globalizing common economy of the European Union as well as a different level of involvement in foreign markets, depending on the level of national economies, can be expected.

Purpose of the Article: A test set of 338,788 companies from across the EU was used to analyse value added associated with each indicator (value added at factor cost, gross (average) value added per person employed, number of workers, enterprise size classes and selected industries, namely manufacturing, construction, engineering, transportation and logistics). The membership of the countries in the European Monetary Union was also taken into account.

Methods: Mathematical and statistical methods of correlation analysis and paired T-test were used for value added analysis.

Findings \& Value Added: The outputs of the analysis indicated a high level of statistical conclusive evidence in terms of the impact of value added on each enterprise size class across the sectors concerned as well as on the structure of production and the number of active workers.
\end{abstract}

Keywords: value added; globalization; global value chain; worker efficiency

JEL Classification: $F 0 ; F 6 ; L O$

${ }^{*}$ Corresponding author: yaroslava.kostiuk@gmail.com 


\section{Introduction}

Global trade as well as the global value-added chain were growing after the great financial crisis of 2008-2009 [1] and this trend was expected to continue in the early 2020s. It is apparent that the COVID - 19 pandemic that has recently hit the world will have unprecedented health and economic consequences. The International Monetary Fund (IMF) declared that the world economy is dealing with the most serious crisis since the 1930's economic crisis [2]. The advanced economies entered this crisis in early 2020 with historically low interest rates, but on the other hand with the highest public debt in the last 60 years. As a result, the public debt of individual economies will increase by a high percentage and the pandemic will continue to test the economic and health readiness of all countries. According to the International Monetary Fund report [3], the impact of the economic environment as well as global value streams after the crisis will depend on a variety of factors that are very difficult to predict. These factors include the duration of the pandemic, supply disruptions, and restrictions on the global financial market, or behaviour changes and purchasing decisions of consumers.

The aim of this paper is to find value added in the EU-28 countries according to the size class, industry, employment and population density.

\section{Literature review}

Globalization is concerned to be a natural process of society's development that cannot be stopped. From an economic point of view, globalization followed the historical development of trade. Increasing the mutual dependence and integration between the world's economies [4] as a result of globalization is concerned as the main driver of economic change through technological progress, in particular the Internet, reducing the transaction costs associated with international trade [5]. Transnational economic cooperation raises the living standards of the population and allows the economies and trade to move forward, and contributes to increasing the freedom to provide services within the European Union [6]. The concept of globalization is closely related to internationalization [7] which can be defined as the internationalization of economic flows. The internationalization of a company takes place if at least one of the company's objects or processes is created outside the country. The main players in globalization are: the United Nations (UN), Multinational Corporations (ZNC), the World Bank (WB), the International Monetary Fund (IMF) and the International Monetary Union. The European Union formed the European Economic and Monetary Union (EMU) which is an extension of the EU single market, including a free trade area subject to common regulations on products and on the free movement of goods, capital, labour, services and persons in the EU and the common currency Euro [8]. As globalization processes grow, researchers are actively involved in creating indicators that are best able to reflect globalization. The bestknown globalization indices are: AT Kearney Globalization Index, CSGR Globalization Index, GlobalIndex, and KOF Globalization Index. The KOF index is probably the most popular globalization index that measures the economic, social and political extent of globalization [9]. Small countries tend to be more globalized than large countries because they are more strongly linked to their neighbouring countries. Large countries conduct a significant part of their business in the domestic market. Therefore, the world's largest economies are not at the top of the global rankings [10]. In terms of the economic globalization index, the latest updates from 2017 show that Germany is ranked 24th, the United Kingdom 23rd, Slovakia 15th, and the Czech Republic 13th. In reference to historical events associated with 2018 [11] such as the referendum on British withdrawal from the EU, the escalation of tariff wars in the US, and the consequent impact on stock 
markets have ushered in a new era of globalization. The trend of globalization after the events as above mentioned and following the events at the turn of the year 2019/2020 (coronavirus pandemic) will be reflected after some time and it will visibly affect the KOF globalization index.

Value Added. In the context of globalization during a period of global recession, value added remains the ultimate goal and measure of the economic performance of multinational economies [12]. During a period of instability in global markets, the realization of increasing profits as well as the efforts to maintain a position in the large competitive market is the strongest motivation driving entrepreneurs, businesses or countries to participate in the global supply chain. Realizing sustainable and stable development of a company helps to eliminate possible financial risk in economies in the future [13]. As the information technologies grow and expand, people have a deeper understanding of added value and it is expected that added value can only be created through the synergy of production and technological development [14]. From a macroeconomic point of view, value added is an indicator that measures the financial performance and competitiveness of each member of the global supply chain. The business objective should reflect its efforts to achieve a certain future state [15], therefore countries analyse the flow of business values by synthesizing the value chain model in order to gain a competitive advantage. The importance of value chain analysis lies in that fact that it understands and analyses the nature and extent of synergies between an organisation's internal activities for a better understanding of strengths and weaknesses [16]. Global practice shows that in the context of increasing the diversification of global production, national economies are becoming more involved in internationalization and influencing a group of segments of the global value chain [17].

Comparison of added value in the EU. It shows that the trend of added value in the European and global conditions after the impact of Covid-19 will change significantly. According to the WTO (World Trade Organization) [18], the outlook for the global economy over the next two years remains highly uncertain. Global trade is expected to decline $13-32 \%$ by 2020 due to the COVID-19 pandemic which will have an adverse impact on added value [19]. In some industries (e.g. services, tourism, air transport, engineering, consumer durables such as cars) we are already seeing a massive drop in sales which will lead to a decrease in added value while the transportation and logistics sectors, and pharmaceutical production, or healthcare will have a declining trend in the creation of added value. Many factors will play a role here. For example, the introduction by the European Union of a higher IMPORT DUTY on Chinese products since the beginning of 2021, the exit of the United Kingdom (the second largest contributor to European added value before Brexit). Other factors include global redundancies, especially in large enterprises. The link between the strong EU economies and the weaker ones (e.g. the Slovak and Czech economies are very dependent on the German economy in terms of production). Another factor is the US-China trade war which has already forced multinational companies to relocate production from China [20]. However, one of the problems [21] is the role of the Global Value Chain (GVC) in specifying sectoral income elasticity. Because intermediate product inputs can be traded more than once between countries in the global production network, gross trade flows may fail to find the original source of added value and overestimate its extent. Once the coronavirus pandemic has subsided, all countries could accelerate their recovery by simplifying the redistribution of staff and resources to gradually update fiscal adjustment and restore their political and financial reserves. Each government should also attach great value to supporting the renewal of the social security network [22]. The countries will become more aware of the need for interconnected international trade while at the same time, the economic gaps of each country will be identified, i.e. which sectors are not fully independent. The results will 
help to improve the plan for surviving a future pandemic in the current 21 st century of technological advancement so that consequences as to health effects and the impact on the global economy, or the global value-added chain, are mitigated to the maximum extent possible.

\section{Material and Methods}

The primary focus of research will be to find the average value added in the manufacturing, construction, engineering, transport and logistics industries in the EU28 countries. The test set contains a total of 338,788 enterprises, of which 205,094 small enterprises with less than 20 employees $(60 \%), 110,825$ medium-sized enterprises with 20 250 employees (33\%), and 22,869 large enterprises with 250 and more employees $(7 \%)$ from all over the European Union. The manufacturing sector includes 195,133 enterprises $(58 \%)$, the construction sector $74,759(22 \%)$, the civil engineering sector $10,929(3 \%)$, and the transportation and logistics sector 57,967 enterprises $(17 \%)$. The test set is based on published statistical data of the European Commission for the period 2013-2017 in the Eurostat-OECD Business Indicator Program (EIP) [23]. The following research objectives were defined: to explore 2 research questions and to verify 2 hypotheses.

Q1: What is value added in each country in which classes (small, medium-sized and large enterprises) and in which sectors (manufacturing, engineering, construction, transportation and logistics)?

Q2: What is the apparent labour productivity (gross value added per person employed) in each country based on available data 2015 - 2017?

H1: The value added in the country is directly dependent on the percentage of each enterprise size class.

H2: The total value added in the country depends on population density, the number of active workers and the production structure.

Eurostat data and their analysis and comparison and visual illustration shown in Figure 1 Average value added at factor cost in EU28 countries and Figure 2 Apparent labour productivity (gross value added per person employed) were used to explore the research questions.

Average value added at factor cost, EUR mil. On a sector basis, the highest value added at factor cost in the EU28 was generated by the manufacturing sector $(72 \%)$, followed by the transportation and communications sector $(19 \%)$, the construction $(7 \%)$ and civil engineering industries (2\%).

Q1: What is the value added in each country in which classes (small, medium-sized and large enterprises) and in which sectors (manufacturing, engineering, construction, transportation and logistics)?

When comparing average value added in each enterprise size class in the sectors concerned, higher value added was in most cases generated in large enterprises from Germany, the United Kingdom, France, and Italy. But in Germany, for example, the civil engineering sector added more value in medium-sized companies than in large ones. This phenomenon is explained by the fact that Germany has more medium-sized enterprises engaged in the civil engineering sector. In terms of the sectoral breakdown, the countries such as Germany and the United Kingdom create the highest value added in large and medium-sized enterprises in the manufacturing industry. Transportation and logistics is another sector with the highest value added, especially in large enterprises. For the reference period, value added in the manufacturing sector rose, on average, to $19.3 \%$, in the construction sector to $14 \%$, in the civil engineering sector to $12.4 \%$, and in the transportation and logistics sector to $12.2 \%$. 
Apparent labour productivity. Apparent labour productivity represents the gross value added per person employed (thousand Euro). Data are taken from the Eurostat database for the available period 2015-2017. If a company wants to increase the value of the company, it must be able to improve the company performance as well as the employee performance.

Q2: What is the apparent labour productivity (gross value added per person employed) in each country based on available data 2015 - 2017?

When comparing the average apparent labour productivity, the highest value added per person employed was created by large manufacturing companies in countries such as Ireland (802.0), Belgium (150.8), the Netherlands (149.2) and Denmark (141.2). On the contrary, the lowest value added was created by small enterprises in countries such as Bulgaria (9.0) and Romania (9.3). In terms of time, no significant changes were experienced. In terms of enterprise size class, the highest apparent labour productivity was achieved by workers in large enterprises. This can be explained by the number of employees, competition among them, and higher standards set in large enterprises. The most interesting is to compare the given indicator for measuring success in different countries. For example, medium-sized enterprises in the construction industry in Austria achieved apparent labour productivity by $€ 30.2$ thousand more than large enterprises. For apparent labour productivity, the EU28 countries can be divided into 3 groups:

- Group of countries with high gross (average) value added per person employed (Ireland, Switzerland, Belgium, Denmark, Austria, Netherlands, UK);

- Group of countries with medium gross (average) value added person employed (Luxemburg, Sweden, Italy, Finland, France, Germany, Spain, Greece);

- Group of countries with low gross (average) value added per person employed (Malta, Cyprus, Slovenia, Estonia, Portugal, Czechia, Hungary, Poland, Slovakia, Croatia, Latvia, Bulgaria and Romania).

Comparison of value added in EU28 countries and value added by workers. The comparison of value added at factor cost in the EU28 countries and gross value added per person employed shows significant differences which means that apparent labour productivity is not directly dependent on value added by government, it depends on various factors.

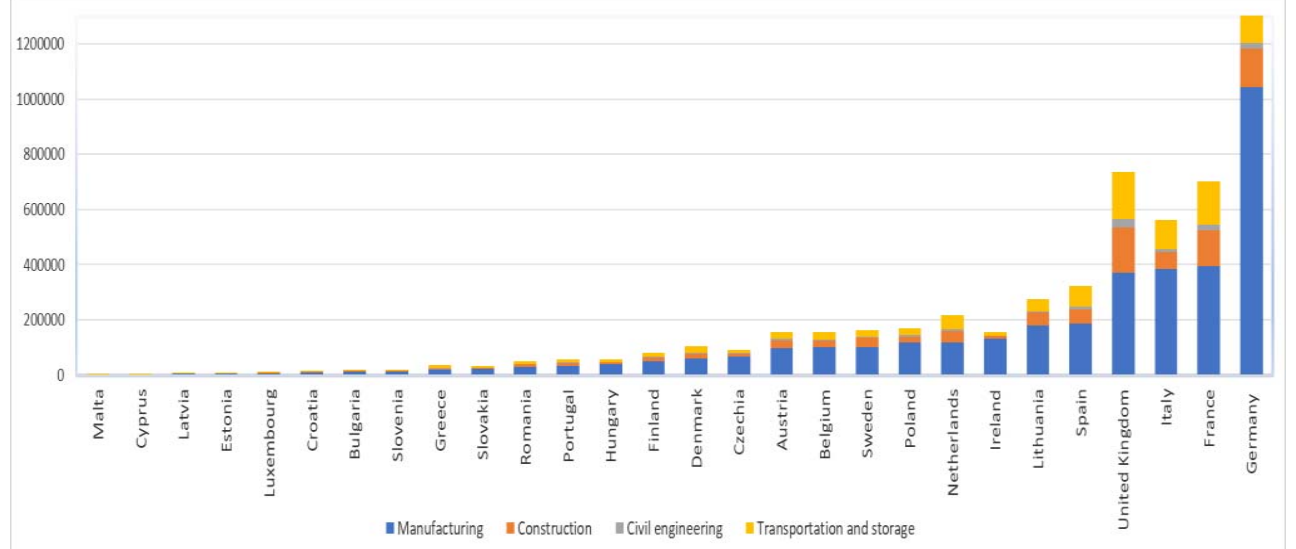

Fig.1. Average value added at factor cost in EU28 countries for the period 2013-2017 (EUR mil.). Source: own production according to Eurostat 


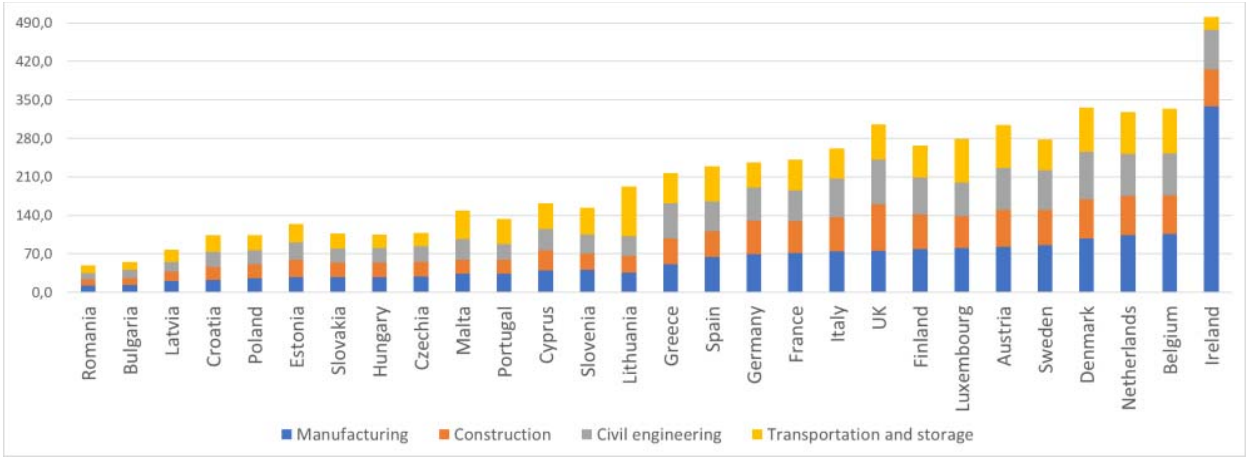

Fig.2. Apparent labour productivity (gross value added per person employed) for the period 20152017 (thousand Euro).

Source: own production according to Eurostat

It depends on factors such as population density, number of employees, labour productivity, or employee performance, and scientific and technological progress, or technical equipment.

For example, Germany as the leader in creating average value added at factor cost was only ranked 13th in the apparent labour productivity ranking, thus placed in the group of medium gross value added per person employed. Once again, it shows the high technological progress in this country where the worker as an individual does not have to add so much value. On the other hand, countries with low gross value added per person employed usually report low average value added at factor cost. This phenomenon is a result of dependent economies where companies do not have the most advanced technical equipment. Therefore, workers have to add more value while frequent failures and repairs of obsolete machines that they inherited from more developed countries are causing long downtimes. Another factor determining on worker value added is the financial motivation, or the country's economic situation. Workers have often the choice whether to stay and work at home, in a country with a developing economy, or to leave to work in a more developed country. If nations belonging to the group of countries with low added value per person employed found investment opportunities for scientific and technological progress, thereby increasing their value on the world market, ensuring appropriate remuneration of workers, using internal national potential to the maximum in order to boost the economy the ranking of the world trade market as well as the value-added market leaders would be utterly different.

Value added depending on diverse factors. As previously mentioned, higher value added depends on the influencing factors that were tested in the following hypotheses. Statistical software "R" was used in the calculation. The correlation method was allocated for the analysis.

H1: The value added in the country is directly dependent on the percentage of each enterprise size class.

Table 1. Correlation analysis of enterprise size classes - Manufacturing.

\begin{tabular}{|c|c|c|c|c|}
\hline & T & Df & P-value & $\begin{array}{c}\text { Mean of the } \\
\text { differences }\end{array}$ \\
\hline From 20 to 49 persons employed & 3.2308 & 28 & 0.003387 & 72037.2 \\
\hline
\end{tabular}




\begin{tabular}{|c|c|c|c|c|}
\hline From 50 to 249 persons employed & 3.232 & 28 & 0.003328 & 62584.34 \\
\hline From 250 persons employed or more & 3.6055 & 28 & 0.001296 & 37137.79 \\
\hline & $p=0,00<0,05 ; \alpha=5 \%$ \\
\hline
\end{tabular}

Added value depends on the percentage of each enterprise size class in the manufacturing industry. Added value increases as the company grows and p-value decreases. The manufacturing industries generate most of value added in large enterprises, so this hypothesis is confirmed.

Table 2. Correlation analysis of enterprise size classes - Construction.

\begin{tabular}{|c|c|c|c|c|}
\hline & T & Df & P-value & $\begin{array}{c}\text { Mean of the } \\
\text { differences }\end{array}$ \\
\hline From 20 to 49 persons employed & 3.5067 & 28 & 0.001668 & 17591,75 \\
\hline From 50 to 249 persons employed & 3.4789 & 28 & 0.00179 & 17201.48 \\
\hline From 250 persons employed or more & 3.5998 & 28 & 0.001315 & 16649.55 \\
\hline \multicolumn{6}{|c|}{$p=0,00<0,05, \alpha=5 \%$} \\
\hline
\end{tabular}

The hypothesis was confirmed for the construction industry that value added depends on the on the percentage of each enterprise size class. Added value increases as the company grows and p-value decreases.

Table 3. Correlation analysis of enterprise size classes - Civil engineering.

\begin{tabular}{|c|c|c|c|c|}
\hline & T & Df & P-value & $\begin{array}{c}\text { Mean of the } \\
\text { differences }\end{array}$ \\
\hline From 20 to 49 persons employed & 3.6132 & 28 & 0.001328 & 2741.651 \\
\hline From 50 to 249 persons employed & 3.4395 & 28 & 0.002054 & 2370.018 \\
\hline From 250 persons employed or more & 3.4735 & 28 & 0.001887 & 1725.88 \\
\hline \multicolumn{4}{|c|}{$\mathrm{p}=0,00<0,05, \alpha=5 \%$} \\
\hline
\end{tabular}

For the civil engineering industry, we do not reject the hypothesis - value added depends on the percentage of each enterprise size class. Highest value is added in medium-sized enterprises. In comparison to other industries concerned, this is the only one where most value is added in medium-sized enterprises.

Table 4. Correlation analysis of enterprise size classes - Transportation and storage.

\begin{tabular}{|c|c|c|c|c|}
\hline & T & Df & P-value & $\begin{array}{c}\text { Mean of the } \\
\text { differences }\end{array}$ \\
\hline From 20 to 49 persons employed & 3.6325 & 28 & 0.00116 & 18149.16 \\
\hline From 50 to 249 persons employed & 3.6174 & 28 & 0.001206 & 16723.88 \\
\hline From 250 persons employed or more & 3.7722 & 28 & 0.0008061 & 8963.375 \\
\hline \multicolumn{4}{|c|}{$\mathrm{p}=0,00<0,05, \alpha=5 \%$} \\
\hline
\end{tabular}

In the transportation and logistics industry, added value depends on the percentage of each enterprise size class. The hypothesis was confirmed. Added value increases as the company grows and p-value decreases. This industry is the second largest sector which generates value added among the industries concerned. The transportation and logistics industry has great potential to create more value added in the future.

H2: The total value added in the country depends on population density, the number of enterprises concerned and the number of active workers

Table 5. Total value added in the country depending on population density

\begin{tabular}{|l|l|l|l|l|}
\hline & T & Df & P-value & Sample estimates: Cor \\
\hline
\end{tabular}




\begin{tabular}{|c|c|c|c|c|}
\hline Persons per square kilometre & 1,596 & 28 & 0.1231 & 0.3040795 \\
\hline \multicolumn{5}{|c|}{$\mathrm{p}=0,1231, \alpha=5 \%$} \\
\hline
\end{tabular}

In examining the dependence of value added on population density, we concluded that value added does not depend on population density, so the hypothesis is rejected.

Table 6. Total value added in the country depending on the number of enterprises concerned.

\begin{tabular}{|c|c|c|c|c|}
\hline & T & Df & P-value & Sample estimates: Cor \\
\hline Podniky & 3.9209 & 28 & 0.0006068 & 0.6170789 \\
\hline \multicolumn{6}{|c}{} \\
\hline
\end{tabular}

In examining the dependence on the number of enterprises concerned, the hypothesis is accepted - added value depends on the number of enterprises concerned.

Table 7. Total value added in the country depending on the number of active workers.

\begin{tabular}{|c|c|c|c|c|}
\hline & T & Df & P-value & Mean of the differences \\
\hline Manufacturing & -3.819 & 28 & 0.0007482 & -1088738 \\
\hline Construction & -4.346 & 28 & 0.0001888 & -468995.7 \\
\hline Civil engineering & -4.3992 & 28 & 0.0001769 & -57676.28 \\
\hline Transportation and storage & -3.9158 & 28 & 0.0005527 & -391425.7 \\
\hline \multicolumn{2}{|c|}{$0.0007482<0,05 ; 0.00018880,05 ; 0.0001769<0,05 ; 0.0005527<0,05 ;$} \\
\hline
\end{tabular}

In examining the dependence on the number of active workers across the sectors concerned, the hypothesis is accepted. The total added value depends on the number of active workers. The higher the number of active workers, the higher the total added value.

\section{Results and Discussion}

This paper discusses two research objectives of the study and two hypotheses. The first research question asked what added value (in millions of Euros) is presented by the countries in which classes and sectors / industries for the reference period 2013-2017. The finding was that according to the sector breakdown, Germany and the United Kingdom create the highest added value in large and medium-sized enterprises in the manufacturing sector. Another sector with high added value is transportation and logistics, especially in large enterprises. The second research question focused on the level of apparent labour productivity (gross value added per person employed (thousands of Euros) reported by the EU28 countries). It was identified that the highest value per person employed was added in large manufacturing companies in countries such as Ireland, Switzerland, Belgium, the Netherlands and Denmark. In contrast, the lowest value added per person employed was created by countries such as Bulgaria and Romania. The comparison of value added at factor cost in the EU28 countries and gross value added per person employed (Figure 1, Figure 2). 2) shows significant differences which indicates that apparent labour productivity is not directly dependent on value added by government. Added value depends on other factors such as population density, number of employees, labour productivity or employee performance, scientific and technological progress, technical equipment of companies, and financial motivation of workers, or labour emigration.

The next part was to test two research hypotheses that were stated. In particular, the dependence of added value on the percentage of each enterprise size class was examined. It was identified that added value in the manufacturing, construction, engineering, transport and logistics industries depends on the percentage of each enterprise size class in the manufacturing sector. 
The second hypothesis was tested by examining whether the total value added of government depends on population density, the number of active employees and the structure of production. The result showed that added value does not depend on population density but it depends on the number of enterprises concerned and the number of active employees.

\section{Conclusion}

The aim of this paper was to find added value in the EU-28 countries by class size, sector / industry, employment and population density. The comparative analysis of value added in the EU indicated that the highest value was added by large companies (250 and more employees) in the manufacturing industry. Due to the COVID-19 pandemic, added value in the manufacturing sector is expected to decline at the turn of the year 2020-2021. Another sector with high value added is transportation and logistics. In it, on the contrary, you can see the trend of growth of value added now and the future growth is expected. Given the dependence between added value created by the EU28 countries and value added by employees, we took a closer look at the reasons why those values are not always linked and the factors that influence their relationship. In testing the stated research hypotheses, the results confirmed a dependence of added value on the percentage of each enterprise size class in all sectors, on the structure of production and the number of active employees. The dependence of value added in the country on population density was not confirmed. We were successful in achieving our goal. Therefore, the final part of our study concluded that the key to creating high value added by workers, or the EU28 countries lies in scientific and technological progress, technical equipment of enterprises and financial motivation of employees.

\section{References}

1. Constantinescu, C., Mattoo, A., Ruta, M. (2020). Policy uncertainty, trade and global value chains: some facts, many questions. Review of Industrial Organization, 57(2), 124.

2. Sokol, M., Pataccini, L. (2020). Winners and losers in coronavirus times: financialisation, financial chains and emerging economic geographies of the covid-19 pandemic. Tijdschrift Voor Economische en Sociale Geografie, 111(3), 401-415.

3. International Monetary Fund (IMF) (2020a, April). Global financial stability report. 3. International Monetary Fund. Retrieved from: https://www.imf.org/en/Publications/ GFSR/Issues/2020/04/14/global-financial-stability-report-april-2020.

4. Cuervo-Cazurrra, A., Mudambi, R., Pedersen, T. (2017). Globalization: Rising skepticism. Global Strategy Journal, 7(2), 155-158.

5. Iouye, T., Joshi A., Hemmatian, I., Robinson, J. (2020). Counteracting globalization's skeptics: How diasporas influence the internationalization preferences of minority entrepreneurs' firms. Global Strategy Journal, 10(1),123-173.

6. Kicova, E. (2016). Trends in facility management in the globalization process. In Kliestik, T. (Eds.), Globalization and Its Socio-economic Consequences: 16th International Scientific Conference (pp. 864-869 ). Rajecke Teplice, Slovak Republic.

7. De Massis, A., Frattini, F., Majocchi, A., Piscitello, L. (2018). Family firms in the global economy: Toward a deeper understanding of internationalization determinants, processes, and outcomes. Global Strategy Journal, 8(1), 3-21. 
8. European Parlament: Information sheets on the European Union (2020, April). History of economic and monetary union. Retrieved from: https://www.europarl.europa.eu/ factsheets/sk/sheet/79/historia-hospodarskej-a-menovej-unie.

9. Gygli, S., Haelg, F., Potrafke, N., Sturm, J.-E., (2019). The KOF Globalisation Index Revisited, Review of International Organizations, 14(3), 543-574.

10. KOF Swiss Economic Institute (2019, October 23). KOF Globalisation Index: Weaker World Trade Slowing Globalisation. Retrieved from: https://kof.ethz.ch/en/news-andevents/media/press-releases/2019/10/weaker-world-trade-slowing-globalisation.html.

11. Gygli, S., Haelg, F., Potrafke, N., Sturm, J.-E., (2019). The KOF globalisation index Revisited. Review of International Organizations, 14(3), 543-574.

12. Antoniuk, L, Cherkas, N. (2018). Macro level analysis of factors contributing to value added: technological changes in European countries. Problems and Perspectives in Management, 16(4), 417-428.

13. Kliestik, T., Valaskova, K., Lazaroiu, G., Kovacova, M., Vrbka, J. (2020). Remaining financially healthy and competitive: The role of financial predictors. Journal of Competitiveness, 12(1), 74-92.

14. Liang, Y., Luo, X., Yang, S. (2018). Research on Ways of Value-Added of Transformer Enterprise Based on Manufacturing Servitization. In IOP Conference Series: Materials Science and Engineering, 394(4), (pp 1-6).

15. Siekelova, A., Kovacova, M., Adamko, P., Stehel, V. (2019). Profit management as an instrument for SMEs developing: The case for Slovakia. Marketing and Management of Innovations, 3, 285-296.

16. Lee, J. (2018). Development of value chain model for design consultancies - Focus on product design consultancies. Archives of Design Research, 31(3), 33-47.

17. Koval, V., Duginets, G., Plekhanova, O., Antonov, A., Petrova, M. (2019). On the supranational and national level of global value chain management. Entrepreneurship and Sustainability, 6(4), 1922-1937.

18. World Trade Organization (WTO) (2019, June 22). Trade falls steeply in first half of 2020. World Trade Organization. Retrieved from: https://www.wto.org/english/ news_e/ pres20_e/ pr858_e.htm\#f ntext-1.

19. Rincon-Aznar, A., Mao X., Tong M. (2020). Global value chains and economic dislocations: introduction. National institute economic review. National Institute of Economic and Social Research, 25, R1-R3.

20. Fritsch M., Matthes J. (2020). On the relevance of global value chains and the intraEuropean division of labour. National Institute of Economic and Social Research, 252, R4-R18.

21. Trigg, A. (2020). Thirlwall's Law and uneven development under Global Value Chains: a multi-country input-output approach. Journal of Economic Structures, 9(4), $1-22$.

22. International Monetary Fund (IMF) (2020b, July 13). Regional economic outlook: Middle East and Central Asia. International Monetary Fund. Retrieved from: https://www.imf.org/en/Publications/REO/MECA.

23. European Statistical Office (Eurostat) (2020, April 27). Entrepreneurship indicator programme. Retrieved from: https://ec.europa.eu/eurostat/web/structuralbusinessstatistics/entrepreneurship/ indicators. 